\title{
Silahlı Çatışmalar Sirasında Kültürel Malların Korunması Rejimi: Tarihsel Gelişimin Analizi
}

The Regime for Protecting Cultural Property during Armed Conflicts:

An Analysis of the Historical Development

\section{Elvan ÇOKIŞLER}

Dr. Arş. Gör., Uluslararası İlişkiler Bölümü, Adnan Menderes Üniversitesi

\section{Bu makaleye atıf için}

Çokişler, Elvan, "Silahlı Çatışmalar Sırasında Kültürel Malların Korunması Rejimi: Tarihsel Gelissimin Analizi", Uluslararası İlişkiler, Cilt 16, Sayı 61, 2019, s. 55-74, DOI: $\underline{10.33458 / \text { uidergisi.541532 }}$

Makaleye Erişim İçin: https://dx.doi.org/10.33458/uidergisi.541532 


\title{
Silahlı Çatışmalar Sırasında Kültürel Malların Korunması Rejimi: Tarihsel Gelişimin Analizi
}

\author{
Elvan ÇOKIŞLER \\ Dr. Arş. Gör., Uluslararası İlişkiler Bölümü, Nazilli İIBF, Adnan Menderes Üniversitesi, Aydın. \\ E-posta: elvanoz@hotmail.com
}

\section{ÖZET}

$\mathrm{Bu}$ araştırmada, silahlı çatışmalar sırasında kültürel malların korunması rejiminin tarihsel gelişimi incelenmiştir. Tarihsel gelişim üç ana başlıkta ele alınmıştır. Birinci başlıkta, antik dönemlerden 18. yüzyıla kadarki süreç, rejimin felsefi alt yapısını oluşturan görüşler ışığında açıklanmıştır. İkinci başlıkta 19. yüzyılda görülmeye başlanan ilk somut çabalar teamülün oluşumu açısından ele alınmış, üçüncü başlıkta ise 20. yüzyıl çabaları rejimin kodifikasyonu açsından incelenmiştir. Bu inceleme, kültürel malların tarih boyunca stratejik kullanıma açık olduğunu, koruma çabalarının büyük savaşlardan sonra hız kazandığını ve kodifikasyon çabalarının silahlı çatışmaların değişen doğasından kaynaklanan büyük zararlara cevap verme refleksiyle geliştiğini göstermiştir. Bulgular, şimdiden öngörülemeyecek olan yeni stratejik kullanımlar karşısında, bugünün kodifikasyon çabalarının yetersiz kalmaya mahkum olduğu şeklinde yorumlanabilir.

Anahtar Kelimeler: Kültürel Mal, Kültürel Malların Korunması, 1954 Lahey Sözleşmesi, Roerich Paktı, OIM Antlaşması.

\section{The Regime for Protecting Cultural Property during Armed Conflicts: An Analysis of the Historical Development}

\begin{abstract}
This research deals with the historical development of the regime for protecting cultural properties during armed conflicts. The historical development is addressed in three sections: The first section explains the process from antiquity through the 18th century in light of the views that form the philosophical background of the regime. The second section discusses the initial tangible efforts which appeared in the 19th century with regard to the establishment of customary law, while the third section handles the 20th century endeavors in terms of the codification of the regime. The research has shown that, throughout history cultural property has been open for strategic use, efforts for protecting it accelerated particularly after great wars and codification efforts improved as a reaction to big damages stemming from changing nature of armed conflicts. These findings may be interpreted as indicating that today's protection efforts are bound to be insufficient for the future strategic uses of cultural property that are unpredictable from today's vantage point.
\end{abstract}

Keywords: Cultural Property, Protection of Cultural Property, 1954 The Hague Convention, The Roerich Pact, The OIM Convention. 


\section{Giriş}

Kültürel mal tanımı, savaşlar sırasında gözlemlenen büyük zararlar sonrasında, ilk kez 1954 yılında yapılmıştır. ${ }^{1} 1954$ tarihli “Lahey Silahlı Çatışma Halinde Kültür Mallarının Korunması Sözleşmesi”nde kültürel mal "kaynak ve sahiplerine bakılmaksızın insanlığın ortak kültür mirası için önemli taşınır ve taşınmaz malların tümü” şeklinde tanımlanmıştır. Bunlar sözleşmede; (i) dini veya laik, tarihi veya sanatsal olmak üzere anıtlar; (ii) arkeolojik alanlar; (iii) yapı toplulukları; (iv) sanat eserleri; (v) el yazmaları, kitaplar ve diğer sanatsal, tarihi veya arkeolojik objeler; (vi) bilimsel koleksiyonlar ve kitap, röprodüksiyon, arşiv ve koleksiyonları, olmak üzere altı kategori ve bunları koruma ve teşhir amaçlı bina, sığınak ve anıt merkezler olarak belirlenmiştir. ${ }^{2} 1954$ tarihli bu ilk tanımdan sonra, özellikle UNESCO önderliğinde hazırlanan diğer uluslararası metinlerde, koruma altına aldığı alanlar aynı kalmakla birlikte, kültürel mal tanımı yerine kültürel miras da kullanılmaya başlanmıştır. ${ }^{3}$ Kültürel mirası oluşturan kültürel malların tarih boyunca maruz kaldığı en büyük tehlike savaşlar olmuştur.

Uluslararası İlişkiler literatüründe rejim, "aktörlerin beklentileri nedeniyle bir araya geldikleri belirli bir alandaki ilkeler, normlar, kurallar ve karar alma süreçleri” şeklinde tanımlanmaktadır. ${ }^{4}$ Araştırma, kültürel malların korunması rejimini, rejimin felsefi altyapısının nasıl geliştiğini ve kurallarının neler olduğunu incelemektedir. Bu amaçla tarihsel gelişim üç dönemde ele alınmıştır. İlk başlıkta, antik dönemlerden 18. yüzyıla kadarki süreç, rejiminin felsefi alt yapısını oluşturan düşünürlerin görüşleri açısından ele alınmış, ikinci başlıkta, 19. yüzyıla ait ilk yazılı belgeler, bu belgelerin hazırlanmasına neden olan olaylarla birlikte değerlendirilmiş ve teamülün ortaya çıkışı açıklanmıştır. Üçüncü başlıkta ise 20. yüzyıl metinleri normlar ve kurallar açısından ele alınarak rejimin kodifikasyonu incelenmiştir. Tarihsel gelişim, koruma fikrinin her dönemin kendi ruhuna uygun biçimde ele alındığını, koruma çabalarının büyük savaşlardan sonra hız kazandığını ancak kültürel malların zarar görmeye devam ettiğini ortaya koymuştur. Bu durum rejimin başarısının sorgulanmaya başlanmasına sebep olmuştur. Rejimin başarılı ya da başarısız, yeterli ya da yetersiz olduğunun ortaya konabilmesi, öncelikle, rejimin ne olduğunun ve nasıl geliştiğinin bilinmesi ile mümkündür. $\mathrm{Bu}$ araştırmanın amacı, rejimin gelişimini tarihsel perspektifle incelemektir.

\section{Kültürel Malların Korunması Doktrininin Gelişimi: Başlangıcından 18. Yüzyıla Kadar}

Kültürel malların savaşlar sırasında nasıl korunması gerektiği konusundaki en erken çabalar, filozofların ve din insanlarının, savaşlarda tapınaklar başta olmak üzere her türlü kutsal alana ait

1 Gael M. Graham, "Protection and Reversion of Cultural Property: Issues of Definition and Justification”, The International Lawyer, Cilt 21, No.3, 1987, s.755.

2 “1954 Lahey Silahlı Bir Çatışma Halinde Kültür Mallarının Korunmasına Dair Sözleşme”, Md.1, http://ua.mfa.gov.tr/ detay.aspx?2169 (Erişim Tarihi 14 Eylül 2017).

3 Günümüzde her ikisi de birbirlerinin yerine kullanılabilmekle birlikte; kültürel mal ifadesi resmi bir sahiplik söylemi taşırken, kültür mirası, miras yoluyla nesiller arasında aktarılmaya vurgu yapmaktadır. Roger O'Keefe, “The Meaning of ‘Cultural Property' Under the 1954 Hague Convention”, Netherlands International Law Review, Cilt 46, No.1, 1999, s.26. Akipek'in dikkat çektiği uyarılara istinaden, incelenen metinlerde geçen cultural property'nin karşılığ olarak, bu araştırmada kültür malı yerine kültürel mal ifadesi kullanılmıştır. Serap Akipek, "Dünya Kültürel ve Doğal Mirasının Korunmasına Dair Sözleşmenin Değerlendirilmesi”, Ankara Üniversitesi Hukuk Fakültesi Dergisi, Cilt 50, No.4, 2001, s.17 (dipnot 21). Ancak, 1954 Sözleşmesi’nin resmi Türkçe metninde kullanılan kültür malı ifadesine sadık kalınmıştır.

4 Stephen D. Krasner, "Structural Causes and Regime Consequences: Regimes as Intervening Variables", International Organization, Cilt 36, No.2, 1982, s.186. 
kültürel malların intikam duygularıyla tahrip edilmemesi çağrıları şeklindedir. ${ }^{5}$ Örneğin antik dönemde, tapınaklar savaşlar sırasında dokunulmaz kabul edilmiş, sığınanlar da sığınmacı olarak görülmüşlerdir. ${ }^{6}$ Ancak, farklı tanrılara inanan toplumları karşı karşıya getiren savaşlarda tanrı gazabından kaçınma esaslı koruma anlayışı geçerliğini koruyamamış, Perslerin ve Galatların Yunan tapınaklarını korkusuzca yağmalamalarını engelleyememiştir. Bu örnek, Rönesans’a kadar devam edecek olan ilahi cezalandırılma korkusundan beslenen koruma fikrinin, sadece aynı kutsal değerleri paylaşan toplumlar için geçerli olduğunu göstermektedir.

Kültürel mallara verilen zararın askeri açıdan sakıncaları M.Ö. 6. yüzyılda Sun $\mathrm{Tzu}^{7}$ ve 19. yüzyılda von Clausewitz ${ }^{8}$ tarafından değerlendirilmiştir. Aralarında yaklaşık 2500 yıl olan iki stratejist, işgal edilen halkın kontrolünü zorlaştıracağı ve ileride girişebilecekleri intikam savaşlarını meşrulaştıracağı gerekçesiyle, mağlup edilmiş düşmanın kültürel mallarına zarar verilmesine karşı çıkmışlardır. ${ }^{9}$

Roma İmparatorluğu dönemine gelindiğinde, fazileti her şeyden üstün tutan Romalı düşünürler, kentlerin yağmalanmasını ahlaki açıdan değerlendirmişlerdir. Polybius’a (M.Ö.202-120) göre " $[\mathrm{b}]$ ir şehir güzelliğini başka yerlerden getirilen ziynetlere değil, kendi halkının faziletlerine borçludur." ${ }^{\prime 10}$ Cicero'ya (M.Ö.106-43) göre ise, herhangi bir askeri fayda sağlamayacaksa kutsal alanlar yok edilmemelidir. ${ }^{11}$ Cicero'nun bu görüşü, ileride askeri gereklilik muafiyeti olarak karşımıza sıklıkla çıkacaktır. Hıristiyanlık döneminde konu yine zamanın ruhuna uygun şekilde, günah açısından ele alınmıştır. Saint Augustin’e (M.S.354-430) göre, ganimet almak için yağma ve talan günahtır. ${ }^{12}$

Örneklerden anlaşılacağı üzere, Orta Çağ’ kadar dini yapılar ve eserlerin korunması üzerinde durulmuş̧tur. Reform ve Rönesans'la birlikte gelişen hümanizm, insan elinden çıkmış her türlü sanat eserinin değerli olduğu düşüncesini yaygınlaştırmıştır. 16. yüzyıldan itibaren, uluslararası hukuk yazarlarının eserlerinde, savaşlar sırasında kültürel malların korunması gerektiğine dair uyarılar artmaya; böylece doktrin de oluşmaya başlamıştır. ${ }^{13}$ Alberico Gentili (1552-1608) savaş sırasında özel mülklerin yanı sıra, kültürel malların da özellikle korunması gerektiğini belirtmiş, ${ }^{14}$ Jacob Przyluski (1512-1554) savaşan her tarafın, dini bir doğası olmasa bile her türlü sanat eserine saygı göstermesi gerektiğini savunmuştur. ${ }^{15}$ Diğer taraftan, Hugo Grotius (1583-1645) Savaş ve Barış Hukuku adlı eserinde "ulusların hukuku kutsal şeyleri, Tanrıya ya da tanrılara adanmış şeyleri hariç tutmaz. ...

5 Harvey E. Oyer III, “The 1954 Hague Convention for the Protection of Cultural Property in the Event of Armed Conflict-Is It Working-A Case Study: The Persian Gulf War Experience”, Columbia-VLA Journal of Law \& the Arts, No.23, 1999, s.49; Jiri Toman, Protection of Cultural Property in the Event of Armed Conflict, Hampshire, Dartmouth Publishing Company, 1996, s.4.

6 Christiane Johannot-Gradis, "Protecting the Past for the Future: How does Law Protect Tangible and Intangible Cultural Heritage in Armed Conflict?”, International Review of the Red Cross, No.900, 2015, s.1257.

7 Sun Tzu, The Art of War, T. Cleary (Çev.), Londra, Shambhala, 1998, s.76-77.

8 Carl von Clausewitz, Savaş Üzerine, H. Fahri Çeliker (Çev.), İstanbul, Özne Yayınları, 1999, s.374-375.

9 Peter Stone, “The Challenge of Protecting Heritage in Times of Armed Conflict”, Museum International, Cilt 67, No.1-4, s.44.

10 Mackenzie Warner, "The Last Poor Plunder from a Bleeding Land: The Failure of International Law to Protect Syrian Antiquities”, Brooklyn Journal of International Law, Cilt 42, No.1, 2016, s.488; Toman, Protection of Cultural Property, s.4.

11 Johannot-Gradis, Protecting the Past, s.1257. Cicero'nun bu görüşü, günümüzde askeri gereklilik muafiyeti olarak halen geçerliğini korumaktadır.

12 Toman, Protection of Cultural Property, s.4.

13 Ibid.

14 Roger O'Keefe, The Protection of Cultural Property in Armed Conflict, New York, Cambridge University Press, 2006, s.39.

15 Toman, Protection of Cultural Property, s.4-5. 
Kamusal bir savaşta herkes limit ya da kısıtlama olmadan, düşmandan aldığı şeyin sahibi haline gelir.” diyerek yağmayı meşru gören eski görüşlerin savunucusu olmuştur. ${ }^{16}$ Devletlerin uygulamaları ise bu eski anlayışın tersi yönde ilerlemiş, 1648 Vestfalya Kongresi'nden başlayarak, devletler yağma ve talanı kınamış, yağmalanan malların savaş sonrasında asıl sahiplerine geri verilmesi kararı alınmıştır. ${ }^{17}$

18. yüzyıl düşünürlerinden Emer de Vattel (1714-1767) "insan irkına onur veren ve düşmanın gücüne bir şey katmayan, dikkate değer güzellikteki bazı bina, alan ve objeler [zarardan] esirgenmelidir." diyerek bir taraftan kültürel mal tanımının kapsamını genişletmiş, diğer taraftan askeri gereklilik kavramının önemini dile getiren ilk düşünürlerden biri olmuştur. ${ }^{18}$ Jean-Jacques Rousseau'ya (1712-1778) göre, "savaş insanlar arasında değil, devletler arasındadır." ${ }^{19} \mathrm{Bu}$ yüzden, doğrudan askeri amaçlarla kullanılmayan ibadet alanları, eğitim kurumları, kütüphaneler, sanat ve bilim koleksiyonları gibi insanlık için önemli bazı kültürel malları, özel mülkiyetlerde olduğu gibi, zarardan korunmalıdır. ${ }^{20}$ Rousseau'nun özel mülkiyet kavramını geliştirmesi sayesinde, savaşlar sırasında özel mülkiyet-kamu mülkiyeti ayrımı yapılmaya başlanacak ve böylece kültürel malların özel mülk olarak kabul edilmesi yaygınlaşacak, diğer özel mülkler gibi, dokunulmaz ve zarar verilemez oldukları daha yaygın bir şekilde savunulacaktır. ${ }^{21}$

18. yüzyılda milliyetçiliğin ve ulus devletlerin yükselişi ile birlikte, kültürel mallara atfedilen önem de artmış, sivil mimariye ait anıt ve binalar, ulusal değerleri ve ulusal geçmişi sembolize ettikleri için korunması gereken değerler arasına girmiştir. ${ }^{22}$ Kültürel mallar, bu özelliği sayesinde, özellikle emperyalist hayaller kuran başta Fransa olmak üzere büyük devletlerin de ilgisini çekmeye başlamıştır. Fransız Devrimi ile siyasi ve entelektüel bir çağ atlandığına ve böylece Fransız kültürünün insan ırkının entelektüel lideri olması gerektiğine inanan Napolyon, Fransa'yı dünyanın sanat ve kültür merkezi yapmak için açtığı müzeye envanter oluşturmak amacıyla, seferlerinde ganimet toplamaya, imzalattı̆̆ barış antlaşmalarında sanat eserlerini tazminat olarak almaya başlamıştır. ${ }^{23}$

18. yüzyılda, özellikle, Napolyon'un Mısır'da ve İngiliz birliklerinin Kanada ve Amerika'da tarihi eserlere zarar vermeleri tepki çekmeye başlamış, bu tepkiler sayesinde 1815 Viyana Kongresi'nde, tarihi ve sanatsal eserler konusu da görüşülmüştür. Konferans sonunda yağmalanan eserlerin sahiplerine iadesi konusu barış antlaşmasının maddelerinden biri olarak düzenlenmiştir. ${ }^{24} \mathrm{Bu}$ maddeye göre, "sanat eserlerinin bulundukları yerden alınması adaletin bütün ilkelerine ve modern savaş usullerine

16 Ana Filipa Vrdoljak, "Cultural Heritage in Human Rights and Humanitarian Law”, Ben Naftali (Der.), Human Rights and International Humanitarian Law, New York, Oxford University Press, 2009, s.252; Toman, Protection of Cultural Property, s.5.

17 Vrdoljak, "Cultural Heritage", s.252.

18 Ibid; Toman, Protection of Cultural Property, s. 5.

19 Vrdoljak, "Cultural Heritage”, s.252; Toman, Protection of Cultural Property, s.5.

20 Vrdoljak, "Cultural Heritage”, s.252; Toman, Protection of Cultural Property, s.5.

21 Savaş sırasında kamu-özel mülk ayrımının yarattığı en önemli fark, özel mülkiyet hiçbir şekilde müsadere edilemezken, kamu mallarına el koymanın hatta işgal sırasında intifa hakkı gereği bunlardan gelir elde etmenin mümkün olmasıdır. Ayrıca savaş hukuku belgelerinde özel mülke zararla karşılık vermek yasaklanmışken, argumentum e contrario, kamu mallarına zararla karşılık verilebilir. Diğer taraftan, özellikle taşınmaz kültürel malların pek çoğunun kamu mülkiyetinde olduğu göz önüne alınarak, kültürel malın daha iyi korunabilmesi için bu mallar üzerinde özel mülkiyete izin verilmesi gerektiğine yönelik görüşler de vardır. Bkz. Eric A. Posner, "International Protection of Cultural Property: Some Skeptical Observations”, Chicago Journal of International Law, Cilt 8, No.1, 2006, s.213-233.

22 Johannot-Gradis, Protecting the Past, s.1258.

23 Stanislaw E. Nahlik, "International Law and the Protection of Cultural Property in Armed Conflicts", Hastings Law Journal, Cilt 27, No.5, 1975, s.1071; Toman, Protection of Cultural Property, s.6.

24 Nahlik, International Law, s.1071. 
aykırıdır." ${ }^{25} \mathrm{Bu}$ dönemde kültürel malların korunmasının yeni gelişmekte olan insancıl hukuka uygun biçimde adalet ekseninde ele alındığı görülmektedir.

Buraya kadar, milat öncesi dönemlerden 19. yüzyıla kadar kültürel mallara karşı daha kuvvetli bir hassasiyet sağlanabilmesine imkân veren gelişmeler özetlenmiştir. Görüldüğü üzere, kültürel mallar her dönemin iç dinamiklerine uygun biçimde önemli bir değer olarak addedilmiş ve korunması bu dinamiklerle ilişkilendirilmiştir. Böylece, kültürel malların korunması gerekliği yönündeki doktrin yaygınlaşmış ve 19. yüzyıl çabalarının önünü açmıştır.

\section{Yüzyıl Düzenlemeleri: Teamülün Oluşumu}

19. yüzyıla gelindiğinde, "sanatın ve bilimin, savaşma hakkının bir istisnasını oluşturduğu ve koruma ve gözetmeye değer olduğu fikri, bütün medeni uluslar tarafından” en azından felsefi olarak kabul edilmeye başlanmıştır. ${ }^{26} \mathrm{Bu}$ nedenle 19. yüzyıl, ilk ulusal ve uluslararası düzenlemelerin hayata geçirilmeye çalışıldığı dönemdir. Bu dönemde atılan önemli adımlar; 1863 Lieber Kanunu, 1868 Saint Petersburg ve 1874 Brüksel Deklarasyonları'dır.

\section{Lieber Kanunu}

Konu hakkındaki ilk hukuki ulusal belge, Profesör Francis Lieber tarafından ABD'de hazırlanan ve kısaca Lieber Kanunu olarak bilinen "Sahadaki Birleşik Devletler Ordusu İçin Talimatlar”dır. 24 Nisan 1863 'te hazırlanan ve İç Savaş sırasında Birlik askerlerinin nasıl hareket etmesi gerektiğini belirten bir rehber olan bu talimatnamede, ${ }^{27}$ kültürel malların müsaderesi yasaklanmış ve müstahkem mevkilerde yer alsalar bile kültürel amaçlarla kullanılan binaların tüm olası zararlardan korunması gerekliliği düzenlenmiştir (Md.35).$^{28}$ Ayrıca, sadece sıcak çatışmanın devam ettiği süreçte değil, işgal ve ateşkes durumlarında da kültürel malların korunması düzenlenmiştir; müstahkem mevkide yer alan taşınabilir kültürel malların zararsız tahliyesi mümkün ise, işgal durumunda, barış antlaşması ile nihai yetkili taraf belirlenene kadar, işgal kuvvetlerinin yetkili komutanı kültürel malın müsaderesine karar verebilir (Md.35), fakat hiçbir durumda kültürel mallar gasp ${ }^{29}$ edilemez, hibe edilemez, satılamaz, mülkiyeti alınamaz ve devredilemez, zarar verilemez veya yok edilemez (Md.36). ${ }^{30}$

Lieber Kanunu'nun müsadereye kısmen izin veren 35. maddesi, sonraki uluslararası hukuk düzenlemelerinde kendine yer bulamamıştır. ${ }^{31}$ Sonraki düzenlemelerde de korumanın ön şartı olarak belirlenecek bir ölçüt olan kültürel malların askeri amaçlarla kullanılmıyor olması koşulu ise, ilk kez

25 Toman, Protection of Cultural Property, s.5.

26 Nahlik, International Law, s.1071.

27 Friedrich T. Schipper ve Erich Frank, "A Concise Legal History of the Protection of Cultural Property in the Event of Armed Conflict and a Comparative Analysis of the 1935 Roerich Pact and the 1954 Hague Convention in the Context of the Law of War", Archaeologies: Journal of the World Archaeological Congress, Cilt 9, No.1, 2013, s.14; Vrdoljak, "Cultural Heritage", s.253.

28 Vrdoljak, "Cultural Heritage”, s.253; Warner, The Last Poor Plunder, s.488-489; Sanja Zgonjanin, “The Prosecution of War Crimes for the Destruction of Libraries and Archives during Times of Armed Conflict”, Libraries \& Culture, Cilt 40, No.2, 2005, s.130.

29 Müsadere, malın zorla devlet mülkiyetine alınması; gasp ise malın zorla ve haksız yere kişisel mülkiyete geçirilmesidir.

30 Vrdoljak, "Cultural Heritage", s.253.

31 Ibid. 
Lieber Kanunu ile kodifiye edilmiştir. ${ }^{32}$ Ulusal kimliğin korunması için kültürel alanların önemini belirttiğinden ${ }^{33}$ Lieber Kanunu, başta 1868 Saint Petersburg ve 1874 Brüksel Deklarasyonları olmak üzere, ilerideki düzenlemelere ilham kaynağı olmuştur.

\section{Saint Petersburg Deklarasyonu}

Savaş hukukunun genel kurallarını düzenlemek amacıyla, çok taraflı ilk konferans 1868 'de on yedi ülkenin katılımıyla Saint Petersburg'da toplanmıştır. Konferans sonunda imzalanan Deklarasyon, savaş yöntem ve araçlarının düzenlendiği ilk uluslararası savaş hukuku belgesidir. Deklarasyon’a göre, savaşın tek amacı, düşmanın askeri kuvvetini zayıflatmak ve en kısa sürede kalıcı barışı sağlamaktır. ${ }^{34}$ Deklarasyon'da kültürel mallar özel mülk olarak kabul edilmiş, düşmanı zayıflatmayacaksa, tahribi, yıkımı ve yağması yasaklanmıştır. ${ }^{35}$ Fakat Deklarasyon 1870-1871 yıllarında Fransa-Prusya savaşı sırasında Strasbourg Katedrali ve kütüphanesinin tahrip edilmesini engelleyememiştir. ${ }^{36}$

\section{Brüksel Deklarasyonu}

Kamuoyunda büyük tepki çeken Strasbourg olayları, savaş kurallarının belirlenmesine ve kültürel malların korunmasına yönelik yeni bir uluslararası girişime zemin hazırlamış ve 27 Temmuz 1874'de Brüksel'de toplanan konferans sonrasında "Savaş Hukuku ve Gelenekleri Hakkında Uluslararası Bir Deklarasyon Projesi” kabul edilmiştir. Kısaca Brüksel Deklarasyonu olarak anılan metinde; mülkiyetleri devlete ait olsa bile; din, hayır işleri ve eğitime adanmış kurum ve bunlara ait binalar, sanat ve bilim eserleri, özel mülk kabul edilerek savaş sırasında özel mülkün dokunulmazlığı prensibi kapsamına alınmış; yıkılması, tahrip edilmesi ve müsaderesi yasaklanmış (Md.8), bu binaların bombardımanlarda sakınılması (Md.16-17) ve düşman tarafından açık bir şekilde görülebilmesi için yetki sahibi devlet tarafından, ayırt edici bir şekilde işaretlenmesi gereği düzenlenmiştir (Md.17-18). Ayrıca kültürel mallara yönelik her türlü saldırının yasadışı olduğu ve yargı yoluna başvurulacağı kabul edilmiştir (Md.8). ${ }^{37}$

Deklarasyonun Lieber Kanunu'ndan en büyük farkı, kültürel malların her ne suretle olursa olsun müsaderesini yasaklamasıdır. Koruma ve dokunulmazlığın ön şartı olarak 'kültürel malların askeri amaçlarla kullanılmıyor olması' (Md.17) koşulu ise Lieber Kanunu'ndaki haliyle yer almıştır. $\mathrm{Bu}$ koşul sonraki düzenlemelerde de aynen kabul edilecektir. ${ }^{38}$ Deklarasyon Avrupalı devletlerin askeri yeteneklerinden vazgeçmek istememeleri ve yaklaşan Osmanlı-Rus Savaşı nedeniyle yürürlüğe girememiş olmasına rağmen, ${ }^{39}$ ruhu başta 1899 Lahey Sözleşmeleri olmak üzere sonraki uluslararası hukuk düzenlemelerine can verecektir. ${ }^{40}$

32 Schipper ve Frank, Legal History, s.14.

33 Hannah G. He, "Protecting Ancient Heritage in Armed Conflict: New Rules for Targeting Cultural Property during Conflict with ISIS”, Maryland Journal of International Law, Cilt 30, No.1, 2015, s.169.

34 Tracey Leigh Dowdeswell, “The Brussels Peace Conference of 1874 and the Modern Laws of Belligerent Qualification”, Osgoode Hall Journal, Cilt 54, No.3, 2017, s.827.

35 Johannot-Gradis, Protecting the Past, s.1258.

36 Vrdoljak, "Cultural Heritage", s.253.

37 Toman, Protection of Cultural Property, s.9; Vrdoljak, “Cultural Heritage”, s.253; Zgonjanin, The Prosecution, s.130.

38 Schipper ve Frank, A Concise Legal History, s.14; Vrdoljak, “Cultural Heritage”, s.253-254.

39 Dowdeswell, The Brussels, s.840-841.

40 Toman, Protection of Cultural Property, s.9. 
1868 ve 1874 Deklarasyonları ile 19. yüzyıla kadar oluşmuş kurallar kurumsallaşmıştır. ${ }^{41} \mathrm{Bu}$ sayede 19. yüzyılın sonuna doğru, kültürel malların savaş sırasında korunması hem doktrinde hem de askeri uygulamalarda benimsenen yaygın bir hukuk kuralı haline gelmiştir. Örneğin, 1880 yılında, uluslararası topluma uluslararası hukuk kurallarının oluşturulması konusunda rehberlik etmesi amacıyla Uluslararası Hukuk Enstitüsü tarafından hazırlanan "Kara Savaşı Hukuku ve Gelenekleri” adlı taslak rehberin savaş sırasında kültürel malların korunması konusundaki maddeleri Brüksel Deklarasyonu'ndan aynen alınmıştır. ${ }^{42}$

20. yüzyıla kadar yapılan hukuksal düzenlemelerin ana karakteri; bağlayıcılığı olmayan deklarasyonlar, yürürlüğe giremeyen antlaşmalar, hukuksal düzenlemelere kaynaklık etmeleri amacıyla hazırlanan rehber ilkeler veya sınırlı etkiye sahip ulusal yönetmelikler olarak karşımıza çıkmaktadır.

\section{Yüzyıl Düzenlemeleri: Kodifikasyon}

20. yüzyıl, konu hakkında ilk evrensel ve bağlayıcı düzenlemelerin hayata geçirildiği dönemdir. Dönemin en önemli düzenlemeleri; $1899^{43}$ ve 1907 Lahey Sözleşmeleri, 1949 Cenevre Protokolü ve 1977 Ek Protokolleri ile 1954 Lahey Sözleşmesi ve 1999 İkinci Protokolüdür. 1899 ve 1907 Sözleşmelerine geçmeden önce her iki sözleşmede de, kültürel mal terimi tanımlanmadan ve kullanılmadan, korunmaya değer malların; ibadet, sanat, bilim, eğitim ve hayır işleri için kullanılan binalar olarak sıralandığı belirtilmelidir.

\section{9 ve 1907 Lahey Sözleşmeleri}

1899 Sözleşmeleri, savaş kurallarını belirleyen, dolayısıyla savaşlar sırasında kültürel malların korunmasını da kodifiye eden ilk uluslararası antlaşmadır. 1863 Lieber Kanunu ve 1874 Brüksel Deklarasyonu ile kabul edilen ilkeler büyük ölçüde aynen kabul edilmiştir. 1899 Sözleşmeleri’nde konu, II Sayılı Kara Savaşlarına İlişkin Sözleşme içinde; sivillerin mallarının korunmasına dair hükümlerle genel olarak (Md.28, 47) ve kültürel mallara yönelik iki madde ile özel olarak (Md.27, 56) ele alınmıştır. 1907 Sözleşmeleri’nin kültürel mallarla ilgili maddeleri, IV Sayılı Kara Harbinin Kanunları ve Adetleri Hakkında Sözleşme’nin 27. maddesinde sıralanan kültür mallarının arasına 'tarihi abideler'in eklenmesi ve 56. maddenin küçük ifade değişiklikleri ile yeniden yazılması dışında 1899 Sözleşmesi’nin ilgili maddelerinin aynısıdır.

\footnotetext{
Kuşatmalarda ve bombardımanlarda, aynı zamanda askeri bir amaçla kullanılmamış olmaları şartıyla, ibadete, güzel sanatlara, ilimlere ve hayırseverliğe yönelik binaları, [tarihi abideleri] hastaneleri ve hasta ve yaralıların toplandıkları yerleri korumak için mümkün olduğu kadar gerekli bütün tedbirler alınmalıdır. Kuşatılmış olanlar, bu binaları yahut yerlerini kuşatana önceden tebliğ edilmiş olacak özel ve seçilebilir işaretlerle göstermelidir. (1899 II Sayılı Sözleşme, Md.2744; 1907 IV Sayılı Sözleşme, Md. 275)
}

41 Johannot-Gradis, Protecting the Past, s.1258.

42 Nahlik, International Law, s.1072; Toman, Protection of Cultural Property, s.9.

431899 Sözleşmeleri, kronolojik olarak 19. yüzyıla denk düşmesine rağmen, 20. yüzyılın ruhunu yansıttığı için bu dönemde ele alınması uygun bulunmuştur.

441899 Lahey Sözleşmeleri, http://www.opbw.org/int_inst/sec_docs/1899HC-TEXT.pdf(Erişim Tarihi 07 Ocak 2018).

451907 Lahey Sözleşmeleri, http://askerihukuk.net/FileUpload/ds158941/File/kara_harbinin_kanunlari_ve_ adetleri_hakkinda_sozlesme.pdf, (Erişim Tarihi 07 Ocak 2018). 
Devlete ait olsalar bile, kamu malları, din, hamiyetseverlik ve öğrenim, güzel sanatlar ve ilim kurumlarının malları özel mülkiyet gibi muamele göreceklerdir. Bu tür kurumların, tarihi sanat eserlerine ve ilme tahsis edilmiş binaların her türlü zapt, imha ve tahribi yasaktır ve kanunen takip edilmelidir. (1899 II Sayılı Sözleşme, Md.56; 1907 IV Sayılı Sözleşme, Md.56)

27. maddede geçen "ibadete, güzel sanatlara, ilimlere” ait binalar ifadesi ile kilise, müze, kütüphane ve üniversiteler kastedilmektedir. Aynı maddede yer alan "mümkün olduğu kadar" ibaresi, kültürel malları kısmi bir koruma altına almaktadır. ${ }^{46} \mathrm{Bu}$ durum, askeri gerekliliğin koruma kavramından üstün tutulması şeklinde yorumlanabilir. Aynı maddenin ikinci paragrafına göre, işgal ya da saldırı durumunda kültürel malların korunabilmesi için ilgili devletin bunları ayırt edici şekilde işaretlemiş olması gerekmektedir. Bu madde 1874 Brüksel Deklarasyonu’nun 17. maddesinin benzer şekilde tekrarıdır.

Her iki sözleşmede de, müsadereye açık kapı bırakan Lieber Kanunu'ndan farklı olarak, müsadere, yağma ve gasp kesin bir şekilde yasaklanmaktadır: "tarihi sanat eserlerine ve ilme tahsis edilmiş binaların her türlü zapt, imha ve tahribi yasaktır ve kanunen takip edilmelidir.” (1899 II Sayılı Sözleşme, Md.56; 1907 IV Sayılı Sözleşme, Md.56)

1907’nin getirdiği en büyük yenilik, IX Sayılı Savaş Zamanı Denizden Bombalama Konusunda Sözleşme'nin 5. maddesinde kültürel malların işaretlenmesi için kullanılacak ambleme karar verilmiş olmasıdır (Şekil.1): "Mukimlerin vazifesi, bu abideleri, binaları yahut yerleri üst kısmı siyah, alt kısmı beyaz iki üçgenle diklemesine bölünmüşs sert dikdörtgen panellerden oluşan görünebilir işaretlerle göstermiş olmaktır.” (1907 IX Sayılı Sözleşme, Md.5) ${ }^{47}$

Şekil 1.1907 Lahey Sözleşmesi Ayırt Edici Bayrağı

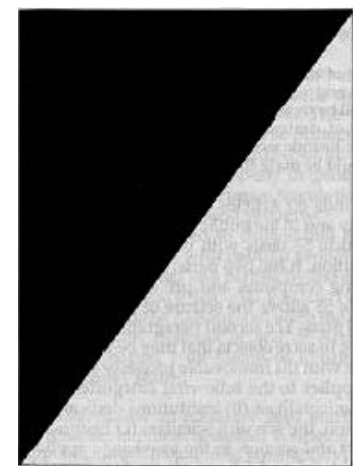

Kaynak: Jiri Toman, Protection of Cultural Property in the Event of Armed Conflict, Hampshire, Dartmouth Publishing Company, 1996, s.12.

1899 ve 1907 Sözleşmeleri birlikte ele alındığında, genel savaş kurallarını belirleyen antlaşmalar olmalarına rağmen, kültürel malları koruma çabalarının yürürlüğe girmiş ilk uluslararası metinleri olmaları bakımından önem taşımaktadır. İki dünya savaşı ve sayısız bölgesel savaş bu sözleşmelere göre yürütülmüştür; taraf olup olmadığına bakılmaksızın, bu sözleşmelerle oluşturulan teamül günümüzde

46 Toman, Protection of Cultural Property, s.10-11.

471907 Lahey Sözleşmeleri,

http://askerihukuk.net/FileUpload/ds158941/File/kara_harbinin_kanunlari_ve_adetleri_hakkinda_sozlesme.pdf, (Erişim Tarihi 07 Ocak 2018). 
tüm devletleri bağlamaktadır. ${ }^{48} \mathrm{Bu}$ sözleşmelerle kültürel malların savaş sırasında korunmasının kodifiye edilmesi yönünde büyük bir ilerleme kaydedilmiş olsa da, kültürel mal tanımının yapılmamış olması ve taşınabilir kültürel mallar konusu ile sözleşmelere aykırı hareketlerin soruşturulması konusunda bir hüküm bulunmaması rejimin çerçevesinin belirlenmesi açısından eksik yönleridir.

\section{İki Dünya Savaşı Arası Dönem: Sonuçsuz Çabalar}

Tüm koruma çabalarına rağmen, kültürel mallar I. Dünya Savaşı́nda zarar görmeye devam etmiştir. Teknolojideki gelişmelerin silahlı çatışmaları da değiştirmesinin etkisiyle bu dönemde savaş hukukuna yeni düzenlemeler getirme arayışına girilmiş ve 1923 Hava Savaşı Kuralları gibi yeni savaş hukuku antlaşmaları imzalanmıştır. Bu antlaşmalar içinde az sayıda madde kültürel mallar ile ilgilidir. Dönemin rejim açısından önemi, kültürel malların korunmasına münhasır uluslararası bir antlaşma yapma çabalarının ortaya çıkmış olmasıdır. Bu doğrultuda atılan adımlar, Altın Haç Örgütü’nün kurulmaya çalışılması ile Hollanda Arkeoloji Enstitüsü’nün raporu, 1939 Uluslararası Müzeler Ofisi (OIM, Office International des Musées) Deklarasyonu ve 1935 Roerich Paktı'dır. Ancak, dönemin kırılgan siyasi yapısı ve yaklaşan yeni savaş dolayısıyla bu çabalar da sonuçsuz kalacaktır.

\section{Altın Haç ve Hollanda Arkeoloji Enstitüsü Raporu}

Daha önce, genel savaş hukuku düzenlemeleri içinde ele alınan kültürel malların korunması konusuna münhasır uluslararası bir antlaşma yapmaya yönelik ilk girişim, Nisan 1915'te, Kızıl Haç'in amaç ve yapısından esinlenilerek savaşlar sırasında kültürel malların korunması konusunda faaliyet gösterecek 'Altın Haç' adıyla uluslararası bir organ oluşturulması fikrinin gündeme gelmesidir. ${ }^{49}$ Ağustos 1915'te Brüksel'de, Almanya, Avusturya-Macaristan ve İsviçre heyetlerinin katıldığı bir uluslararası konferansta konu ele alınmış ve uluslararası bir sözleşmenin ana hatları belirlenmiştir. Bu amaçla, Bern'de uluslararası bir idare kurularak koruma altındaki tarihi anıt ve eserlerin listesinin tutulması ve bu listeyi tanımış olanların savaş zamanında hasım tarafın listedeki kültürel mallara saygı göstermesi kararı alınmıştır. ${ }^{50}$ Ancak bu girişim hayata geçirilememiştir.

Konferansın başarısızlığı üzerine, kültürel malların savaşlar sırasında korunmasına yönelik olası bir uluslararası konferansa hazırlık olarak, 1918 yılında Hollanda Arkeoloji Enstitüsü bir rapor hazırlayarak kültürel mallar üzerinde çalışan OIM gibi uluslararası kuruluşlara iletmiştir. Raporda, kültürel mallara verilen zararın sadece o malın sahiplerini ya da ilgili devleti değil tüm insanlığı etkilediği belirtilerek, kültürel öneme sahip anıt ve alanların etrafinda askersizleştirilmiş alanlar oluşturulması, uluslararası bir statü verilmesi ve bu tür alanların askeri amaçlarla kullanılmayacağının taahhüt edilmesi önerilmiştir. İşgal durumunda da, işgalci devlet bu alanları korumalı ve yerli otoritelerle bunun için işbirliği yapmalıdır. İlgili devletler bu hazırlıklara barış zamanında başlamalı ve uluslararası bir ofis kurularak gözetim ve denetim sağlanmalıdır. ${ }^{51}$ Ancak Hollanda'nın bu girişimi, uluslararası bir sözleşme yapma hedefinde başarıya ulaşamamıştır. Enstitünün çabaları,

48 Nürnberg Uluslararası Askeri Ceza Mahkemesi, Eski Yugoslavya Uluslararası Ceza Mahkemesi (ICTY) ve Uluslararası Ceza Mahkemesi, tüm medeni devletler tarafından kabul edildikleri, savaş kural ve genelliklerini tayin ettikleri için Lahey Sözleşmeleri’nin ve eklerinin teamül hukuku haline geldiğini belirtmiştir. Bkz. Vrdoljak, "Cultural Heritage", 2009, s.254-255; Toman, Protection of Cultural Property, s.10.

49 Toman, Protection of Cultural Property, s.14.

50 Vrdoljak, "Cultural Heritage”, s.256.

51 Ibid, s.256-257. 
kültürel mallara zarar verenlerin cezalandırılması konusunun I. Dünya Savaşı sonunda imzalanan antlaşma maddeleri arasına girmesini sağlamasi ${ }^{52}$ ve konuya münhasır ilk antlaşma girişimi olması bakımlarından önemlidir.

\section{Savaş Zamanında Radyonun Kontrolü ve Hava Savaşı Lahey Kuralları}

1922 yılında, Fransa, İtalya, Japonya, Hollanda, Birleşik Krallık ve ABD’nin katılımıyla gerçekleşen ve havacılık, radyo frekansları ve silah teknolojilerindeki ilerlemelerin saldırı ve savunma tekniklerine etkileri ile bu yeni gelişmeler karşısında 1907 Lahey Sözleşmeleri’nin hala yeterli olup olmadığı Washington Konferansı’nda tartışılmıştır. Yaklaşık üç ay süren konferans sonunda savaş hukukunda yeni düzenlemelerin gerekliliğine karar verilmiş ve 'Savaş Zamanında Radyonun Kontrolü ve Hava Savaşı Lahey Kuralları' antlaşması imzalanmıştır. ${ }^{53}$

Antlaşmada, 1907 Lahey IV. Sözleşmesi'nin 27. ve IX. Sözleşmesi’nin 5. maddeleri aynen kabul edilmiştir (Md.25). Antlaşmanın getirdiği en büyük yenilik, genel korumaya ilave olarak, ilk kez 'çok büyük tarihsel değere sahip' kültürel mallara özel, sadece kültürel malı değil, 500 metre civarındaki alanı da dokunulmaz kılan özel bir koruma rejimi getirmiş olmasıdır (Md.26). I. Dünya Savaşı sırasında Venedik ve Ravenna şehirlerinin havadan bombalanmasına tepki olarak, Hollanda Arkeoloji Enstitüsü’nün raporundan etkilenen İtalyan heyet tarafından geliştirilen bu özel rejim üç konuyu ilk defa gündeme getirmektedir: ${ }^{54} 500$ metreyi aşmayacak silahsızlandırılmış ve bombalanamaz bir dış koruma alanı oluşturulması (Md.26.1; Md.26.3), koruma alanlarının barış zamanında diğer devletlere bildirilmesi (Md.26.2) ve bu alanların suiistimal edilmediğini denetleyecek uluslararası bir heyetin oluşturulması (Md.26.8). Daha önceki hukuksal belgelerde yer almayan bu düzenlemeleriyle metin 1954 Lahey Sözleşmesi’ne yol göstermiştir. Ancak antlaşma imzalanmasına rağmen yürürlüğe girememiştir. ${ }^{55}$

\section{Roerich Paktı}

1929’da, I. Dünya Savaşı’nın Avrupa’nın kültürel malları üzerinde yarattı̆̆ı büyük yıkımın tekrar yaşanmaması için devletlere yol göstermek amacıyla, Rus ressam, yazar ve filozof Nicholas Roerich ve Paris Üniversitesi'nden Georges Chklaver tarafından taslak bir antlaşma metni hazırlanmıştır. Başlangıçta Roerich'in Amerika kıtası devletlerine çağrısıyla bölgesel bir antlaşma olarak düşünülen taslak, uzun yıllar görüşüldükten sonra, nihayet 1935 yılında, Milletler Cemiyeti (MC) ve OIM'in girişimleriyle bir antlaşma metni haline getirilmiş, ancak "zor ve uygunsuz" bulunarak MC'de reddedilmiştir. ${ }^{56}$

Roerich'in antlaşmanın hazırlanmasındaki çabalarından hareketle Roerich Paktı ${ }^{57}$ ya da Washington D.C.'de imzalanmasından dolayı Washington Paktı olarak da anılan antlaşmanın tam adı 'Sanatsal ve Bilimsel Kurumlar ve Tarihi Anıtların Korunması Antlaşması'dır. Pakt başlangıçta, bölgesel

52 Toman, Protection of Cultural Property, s.14.

53 Ibid, s.15-16; Vrdoljak, "Cultural Heritage”, s.257.

54 Toman, Protection of Cultural Property, s.15-16; Vrdoljak, "Cultural Heritage”, s.257.

55 Toman, Protection of Cultural Property, s.15-16; Vrdoljak, "Cultural Heritage”, s.257.

56 Toman, Protection of Cultural Property, s.16-17; Vrdoljak, "Cultural Heritage”, s.257.

57 Harold Kalman, "Destruction, Mitigation, and Reconciliation of Cultural Heritage", International Journal of Heritage Studies, Cilt 23, No.6, 2017, s.546; Schipper ve Frank, A Concise Legal History, s.16. 
düşünülmüş, sonradan evrensel bir antlaşma haline dönüşme yoluna girmiş, MC'de reddedildikten sonra Pan-Amerikan Birliği tarafindan 15 Nisan 1935'te kabul edilerek bölgesel bir antlaşma olarak kalmıştır. $^{58}$

Tüm insanlığın ortak çıkarına olan bilim ve sanattaki ilerlemelerin desteklenmesinin bütün ulusların yükümlülüğü olduğu vurgusuyla başlayan ${ }^{59}$ Pakt’a göre, kültürel mallar, sahip oldukları içsel değerleri ve insanlık için önemleri bakımından insanlığın kültürel hazinesi olarak değerlendirilmeli ve korunmalıdır (Md.1). Kültürel malların ayırt edici bir bayrakla (Şekil 2) işaretlenmesi (Md.3), bu tür yerlerin hükümetler tarafından askeri amaçlarla kullanılmaması şartı (Md.5), her taraf devletin kendi ülkesinde korunması gerekli görülen bina ve anıtların listesini Pan-Amerikan Birliği’ne kayıt ettirmeleri (Md.4) gibi maddeler, önceki antlaşmalardaki düzenlemelerin benzeridir.

Şekil 2. Roerich Paktı Ayırt Edici Amblemi ${ }^{60}$

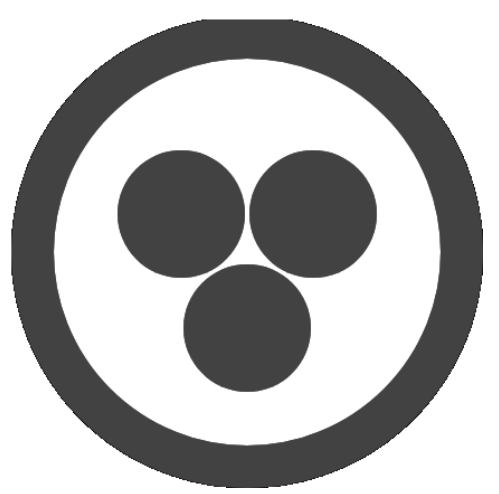

Kaynak: Jiri Toman, Protection of Cultural Property in the Event of Armed Conflict, Hampshire, Dartmouth Publishing Company, 1996, s. 17.

Pakt'ın getirdiği en büyük yenilik, kültürel malların korunmasının, her zaman ve her türlü askeri gereklilikten önce gelmesi gerektiğinin vurgulanmasıdır. ${ }^{61}$ Böylece önceki uluslararası belgelerde ve doktrinde korumaya bir istisna olarak getirilen ve günümüzde de teamülün ve 1954 Sözleşmesi’nin en çok eleştirilen noktalarından birisi olan askeri gereklilik muafiyeti, bu Pakt'ta kabul edilemez bulunmuştur. $\mathrm{Bu}$ açıdan hem önceki hem de sonraki düzenlemelerden farklı ve sekiz maddeden oluşan kısa bir anlaşma olmasına rağmen, daha koruyucudur. Pakt; kültürel malların korunması gerekliliğini daha net ifadelerle belirtmiş, korunacak kültürel malları daha detaylı sıralamış, 'taşınabilir kültürel mallar' ifadesine ilk defa yer vermiş, ayrıca bu alanlarda çalışan personelin de korunmasını düzenlemiştir. Pakt'ın eksikliği ise kültürel malların kapsamını genişletmiş olmasına rağmen, diğerleri gibi, net bir kültürel mal tanımı yapmamış olmasıdır. Kültürel malların korunmasına münhasır ilk düzenleme olan Pakt, 1954 Sözleşmesi’nin dibacesinde anılarak onurlandırılmıştır.

58 Kalman, Destruction, s.546; Keith Suter, "Protecting the World's Cultural Heritage”, Contemporary Review, No.1689, 2008, s.198.

59 Vrdoljak, “Cultural Heritage”, s.267.

60 Nicholas Roerich, 'barış sancağı’ olarak da anılan Roerich amblemindeki üç noktanın, insanlığın en önemli üç kültürel faaliyeti olan sanatı, bilimi ve dini; noktaları çevreleyen kırmızı halkanın ise geçmişi, bugünü ve geleceği birbirine bağlayan süreklilik unsurunu temsil ettiğini belirtmiştir. Bkz. Schipper ve Frank, A Concise Legal History, s.17.

61 Kalman, Destruction, s.546. 


\section{OIM Deklarasyonu}

1930’lu yıllarda İspanya İç Savaşı İkinci Çin-Japon Savaşı, önceki antlaşmaların iç savaş durumlarında uygulanabilir olmadığını ortaya koymuş ve MC'de yeni bir antlaşma hazırlığına girişilmiştir. MC'ye sunulmak üzere, 'Tarihi Binaların ve Sanat Eserlerinin Savaş Zamanı Korunması Hakkında Uluslararası Sözleşmesi Ön Taslağı’ (bundan sonra OIM Antlaşması) OIM’in Uzmanlar Komitesi tarafından hazırlanmıştır. ${ }^{62} 1923$ Hava Savaşı Kuralları ve Roerich Paktı'ndan ilham alınarak hazırlanan ${ }^{63}$ taslak metin, savaş zaruretleri ile en yüksek derecede koruma gerekliliğini uzlaştırmaya çalışan bir çaba içerisindedir. Komite tarafından bu çaba, askeri gereklilikler mazeretiyle ileride devletler tarafından ihlal edilecek yüksek standartlar belirlemek yerine, uygulanabilirliği olan bir çerçeve belirlemek olarak açıklanmıştır. Metnin dibacesinde "bir başyapıtın tahribinin, hangi ulus onu üretmiş olursa olsun, tüm uluslararası toplumun manen yoksullaştırılması” olduğu belirtilmiştir. Hem savaşları hem de iç karışıklıkları kapsayacak şekilde (Md.10) hazırlanan antlaşma; kültürel malların korunması, barış zamanı organize olma ve savunma hazırlıkları; askeri birliklerin eğitimi; askeri düzenlemelerde ve talimatnamelerde kültürel mallara saygılı olunmasını sağlayacak düzenlemeler yapılması; yağma, tahribat ve hırsızlı̆̆ın cezalandırılması için gerekli tedbirlerin alınması gibi temel ilkeler üzerine kurulmuştur. İlk kez bir uluslararası hukuk metninde kültürel malların yok edilmesinin veya tahrip edilmesinin askeri açıdan her hangi bir avantaj sağlamayacağı vurgulanmıştır. ${ }^{64}$

Antlaşma taslağı 1938 sonbaharında MC Genel Kurulu’na sunulmuş, taslağın görüşülmesi için bir konferans toplanması kararı alınmış, ancak, 1939 yılında patlak veren savaş antlaşmanın rafa kalkmasına sebep olmuştur. ${ }^{65}$ Uluslararası bir antlaşma olmak üzere hazırlanan metnin on maddesi, Belçika, İspanya, Yunanistan, ABD ve Hollanda tarafından 1939'da imzalanmıştır ${ }^{66}$ ve OIM Deklarasyonu olarak anılmaktadır.

\section{İkinci Dünya Savaşı ve Kültürel Mallar}

Savaşın başında Fransa ve İngiltere'nin, askeri faaliyetlerini sivil halka zarar vermeden ve mümkün olan her türlü şekilde, insan dehasının kanıtı olan anıtları koruyarak yürüteceklerini ${ }^{67}$ açılklamalarına rağmen, II. Dünya Savaşı kültürel mallar üzerinde daha önce eşi görülmemiş bir yıkım ve tahribata sebep olmuştur.

Bu dönemde, kültürel malların savaşlar sırasında korunmasına yönelik ilk somut adım ABD tarafından atılarak 'Savaş Alanındaki Sanatsal ve Tarihi Anıtları Koruma ve Kurtarma Komisyonu' adlı bir komisyon ve 'Anıtlar, Güzel Sanatlar ve Arşiv Subayları' adlı özel bir askeri birlik kurulmuştur. Kısaca Monuments Men olarak anılan ve aynı adlı bir filme de konu olan bu birliğin görevi, korunacak kültürel malların belirlenmesi, askeri haritalarda işaretlenmesi, harekât sırasında güzergâh üzerindekiler hakkında komutanlara bilgi vermek ve tahrip edilmiş kültürel malların belirlenerek iyileştirme çalışmalarının yapılmasıyd ${ }^{68}$

62 Vrdoljak, "Cultural Heritage", s.268; Toman, Protection of Cultural Property, s.18.

63 Kalman, Destruction, s.546; Vrdoljak, “Cultural Heritage”, s.268.

64 Kalman, Destruction, s.546; Toman, Protection of Cultural Property, s.18; Vrdoljak, “Cultural Heritage”, s.268.

65 Vrdoljak, "Cultural Heritage”, s.269; Toman, Protection of Cultural Property, s.19.

66 Vrdoljak, "Cultural Heritage”, s.269.

67 Toman, Protection of Cultural Property, s 20.

$68 \mathrm{He}$, Protecting, s.172-173. 
1943 yılında imzaladıkları Müttefikler Arası Deklarasyonla 18 müttefik, savaş sırasında gerçekleşen her türlü yağma, talan ve müsadereyi lanetlediklerini ve her ne şekilde olursa olsun savaş alanlarındaki kültürel malların ve sanat eserlerinin ticaret ve transferini tanımayacaklarını açıklamışlardır. Nitekim I. Dünya Savaşı sonunda imzalanan ateşkes ve barış antlaşmalarında olduğu gibi, II. Dünya Savaşı sonunda imzalananlarda da tarihi eserler, müze eserleri ve sanat eserlerinin sahiplerine iadesi konusu da düzenlenmiştir. ${ }^{69}$ Buna rağmen, II. Dünya Savaşı́nda yaşananlar, devletlerin barış zamanındaki tüm iyi niyetli girişimlerine rağmen, savaş zamanında kültürel malların korunmasının mümkün olmadığını göstermiştir.

\section{Cenevre Sözleşmeleri ve 1977 Ek Protokolleri}

Mevcut savaş hukuku düzenlemelerinin II. Dünya Savaşı'nda yetersiz kalması; savaşın doğası, teknikleri ve teknolojilerindeki değişiklikler, devletleri savaş hukuku kurallarını yeniden düzenlemeye itmiştir. Bu amaçla 1949 yılında Cenevre'de toplanan konferans sonucunda günümüzde hala geçerli olan ve çatışma kurallarının, savaş hukukundan insancıl hukuka evrilmesini sağlayan Cenevre Sözleşmeleri kabul edilmiştir.

1949 Cenevre Sözleşmeleri, 1899 ve 1907 Lahey Sözleşmelerinde olduğu gibi, kültürel malların korunması konusunu münhasıran ele almaz; konu Lahey Sözleşmeleri’nde olduğu gibi, sivillerin korunması başlığı altında genel hatlarıyla ele alınır, mevcut teamül kuralları ve 1899 ve 1907 Sözleşmeleri tekrar edilir.

IV Sayılı Harp Zamanında Sivillerin Korunmasına Dair Cenevre Sözleşmesi'nin 53. maddesine göre; "Ferden veya müştereken hususî şahıslara, devlete veya amme topluluklarına, içtimai teşekküllere veya kooperatiflere ait menkul ve gayrimenkul malların imhası, askerî harekât bu imhayı kat'i olarak zaruri kıldı̆̆ı haller müstesna, yasaktır.”70

$\mathrm{Bu}$ madde ile kültürel malların tahribatı ve yok edilmesi yasaklansa da, askeri gereklilikler sebebiyle kültürel mallara zarar verilebilmesi muafiyeti, istisnai bir şart olarak geçerliliğini korumaktadır. Yağmanın (Md.33.2) ve koruma altına alınmış mallara yönelik misilleme hareketlerinin yasaklanması (Md.33.3) da kültürel malların korunmasını kapsayan genel hükümlerdir. Kültürel malların korunması gerektiği yönünde önceki düzenlemelerde yer alan temel fikirler kabul edilmekle birlikte, koruma detaylandırılmamış, işaretleme gibi konulara yer verilmemiştir. 1949 Sözleşmelerinin kültürel malların korunması ile ilgili eksik kalan yönleri 1954 Lahey ve 1977 Ek Protokolleri ile giderilmeye çalışılmıştır. Kronolojik olarak kendisinden önce yapılmış olmasına rağmen, bağlam bütünlügü gereği, önce 1977 Ek Protokollerinin ele alınması tercih edilmiştir.

1977 Ek Protokolleri ${ }^{71}$ ile bir yandan insancıl hukuk gelişirken, diğer yandan kültürel malların korunması için bir adım daha atılmıştır. Uluslararası silahlı çatışmaları kapsayan Ek Protokol I ve uluslararası olmayan silahlı çatışmaları kapsayan Ek Protokol II olmak üzere iki protokolden oluşan

69 Toman, Protection of Cultural Property, s.20.

70 Melike Batur Yamaner, et al., 12 Ağustos 1949 Tarihli Cenevre Sözleşmeleri ve Ek Protokolleri, İstanbul, Galatasaray Üniversitesi Hukuk Fakültesi ve International Committee of the Red Cross, 2016, s.139.

7112 Ağustos 1949 Tarihli Cenevre Sözleşmelerine Ek Uluslararası Silahlı Çatışmaların Mağdurlarının Korunmasına İlişkin Protokol (I. Protokol): 1125 UNTS 3, 8.Haziran.1977 (yürürlüğe giriş: 7 Aralık 1978); 12 Ağustos 1949 Tarihli Cenevre Sözleşmelerine Ek Uluslararası Olmayan Silahlı Çatışmaların Mağdurlarının Korunmasına İlişkin Protokol (II. Protokol), 1125 UNTS 609, 8 Haziran 1977 (yürürlüğe giriş: 7 Aralık 1978). Türkiye bu protokollere taraf olmamakla birlikte, teamül hukuku haline gelmiş Protokollerin ilgili maddeleriyle bağlıdır. 
1977 Protokollerinin her ikisinde de koruma hükümleri birbirine benzer şekilde ele alınmıştır. Ek Protokol I'in 53. maddesi münhasıran kültürel malların korunmasına ayrılmıştır:

Kültürel malların ve ibadet yerlerinin korunması Silahlı Çatışma Halinde Kültürel Malların Korunması Hakkındaki 14 Mayıs 1954 tarihli Lahey Sözleşmesinin ve diğer ilgili uluslararası kaynakların hükümlerine halel gelmemek üzere aşağıdakiler yasaklanmıştır:

a) İnsanların kültürel ve ruhani miraslarını oluşturan tarihi anıtlar, sanat eserleri ya da ibadet yerlerine karşı yöneltilen muhasamat eylemleri gerçekleştirmek,

b) Bu malları askeri çalışmaların desteklenmesi için kullanmak,

c) Bu tür malları misilleme hedefi haline getirmek. ${ }^{72}$

Ek Protokol II’nin “Kültürel varlıkların ve ibadet yerlerinin korunması” başlıklı 16. maddesine göre ise şunlar yasaktır:

Silahlı Çatışma durumunda kültürel malların korunması için 14 Mayıs 1954 tarihli Lahey Sözleşmesinin hükümleri saklı kalmak üzere, halkların kültürel ve manevi miraslarını oluşturan tarihi anıtlara, sanat eserlerine ya da ibadet yerlerine karşı herhangi bir düşmanca davranışta bulunmak ve bu yapıları askeri çabaları desteklemek için kullanmak. ${ }^{73}$

Ek Protokol I'in 52.2 maddesinin ${ }^{74}$ yorumu gereği, eğer bir kültürel mal ancak askeri amaçlarla kullanılıyorsa ve hedef alınması ancak kesin bir askeri avantaj sağlayacaksa askeri gereklilik muafiyeti öne sürülebilir, ${ }^{75}$ her halükarda bu alanlar misilleme ve zararla karşılık hedefi olamazlar (Md.53.c). ${ }^{76}$ Ek Protokol I’in 85.4.d maddesi uyarınca şunlar Cenevre Sözleşmeleri ve Ek Protokollerin ağır ihlali sayllacaktır:

Halkın kültürel ve ruhani mirasını teşkil eden ve örnek olarak yetkili bir uluslararası örgüt çerçevesinde, özel düzenleme ile özel koruma [verilen, ${ }^{77}$ açıkça tanınan tarihi abideler, sanat eserleri veya ibadet yerlerini saldırının hedefi haline getirmek suretiyle, karşı tarafın Madde 53

(b) bendini ${ }^{78}$ ihlal ettiğine dair delil olmadığı ve açıkça ilgili tarihi abideler, sanat eserleri ve ibadet yerleri askeri hedeflerin yakın civarında bulunmadığı durumlarda, aşırı tahribata yol açmak.

$\mathrm{Bu}$ madde gereği, sadece savaş hukuku kapsamında belirlendiği şekilde askeri amaçlarla kullanılmayan kültürel mallar ya da 1954 Sözleşmesi ile Özel Koruma veya 1999 İkinci Protokol ile Gelişmiş Koruma altına alınmış olanlar değil, Dünya Kültür Mirası Listesi gibi özel rejimlerle koruma altına alınmış kültürel mallara yönelik saldırılar da ağır ihlalleri oluşturmaktadır. ${ }^{79}$

72 Yamaner et al., Cenevre Sözleşmeleri, s.215.

73 Ibid, s.274.

74 Maddenin tam metni şu şekildedir: "Saldırılar sadece askeri hedeflerle sınırlı olacaktır. Mallar söz konusu olduğunda askeri hedefler, doğaları, konumları, amaçları ya da kullanımları gereği askeri eylemlere etkin bir katkıda bulunan ve tamamen ya da kısmen yok edilmesi, ele geçirilmesi ya da etkisiz hale getirilmesi durumunda, mevcut koşullar altında, kesin bir askeri avantaj sağlayan objelerle sinırlıdır."

75 Schipper ve Frank, A Concise Legal History, s.21.

76 Orijinal resmi metinde "reprisal" olarak kullanılan kelime, ICRC çevirisinde misilleme olarak çevrilmişse de, 'reprisal'ın uluslararası hukuktaki asıl karşılı̆̆ı 'zararla karşılık'tır.

77 Orijinal resmi metindeki "special protection has been given" ifadesi, çeviri metinde "özel koruma verimli” olarak yazılmıştır. İfadenin doğrusu "özel koruma verilen” olmalıdır.

78 Madde 53(b), bu malların askeri faaliyetlerin desteklenmesi için kullanılmaması hakkındadır.

79 Bu maddeden hareketle, Yugoslavya İç Savaşı sırasında, Dünya Kültür Mirası Listesi’ne yer alan Dubrovnik tarihi şehir merkezinin bombalanması, silahlı çatışmalar hukukunun ağır ihlalidir. 
Ek Protokollerin konuya getirdiği yenilik, ilk defa bir silahlı çatışmalar hukuku düzenlemesinde, hem uluslararası hem de uluslararası olmayan silahlı çatışmalarda kültürel malların koruma altına alınmasıdır. 1954 Lahey Sözleşmesi de uluslararası olan ve olmayan çatışmaları kapsamakla birlikte, Ek Protokoller; hem genel savaş hukuku düzenlemesi olmaları, hem de teamül hukuku yaratmış olmaları nedeniyle önemlidir.

\section{Lahey Silahıı Bir Çatışma Halinde Kültür Mallarının Korunmasına Dair Sözleşme}

Konuya münhasır ilk ve tek uluslararası sözleşmenin imzalanmasına giden yol, UNESCO'nun 1949 yılında, kültürel değere sahip bütün nesnelerin silahlı çatışmaların olası sonuçlarına karşı korunması konusundaki 6.42 sayılı kararıyla açılmıştır. ${ }^{80}$ Bu karar üzerine, taslağı hazırlanan ancak savaşın başlamasıyla askıya alınan 1939 OIM Antlaşması, UNESCO önderliğinde yeniden gündeme getirilmiş, ${ }^{81} 86$ devletin katıldığı konferans sonunda 14 Mayıs 1954 tarihinde 'Lahey Silahlı Bir Çatışma Halinde Kültür Mallarının Korunmasına Dair Sözleşme’ ile Sözleşme’nin uygulanmasına yönelik pratik hükümleri düzenleyen 'Silahlı Bir Çatışma Halinde Kültür Mallarının Korunmasına Dair Olan Sözleşme'nin Tatbikatına Ait Tüzük' ve opsiyonel olarak taraf olunan ${ }^{82}$ Protokol imzalanmıştır. ${ }^{83}$ Sözleşme; I Korunmaya Dair Genel Hükümler (7 madde), II Özel Korunma (4 madde), III Kültürel Malların Nakliyatı (3 madde), IV Personel (1 madde), V Belirtici İşaret (2 madde), VI Sözleşmenin Tatbik Sahası (2 madde), VII Sözleşmenin Tatbiki (9 madde) ve Son Hükümler (12 madde) olmak üzere toplam 8 bölüm ve 40 maddeden oluşmaktadır. Tüzük ise 4 bölüm ve 21 maddedir. 2018 yılı itibari ile Sözleşme'ye 127, Protokol’e ise 104 ülke taraftır. ${ }^{84}$

Sözleşmenin dibacesinde 1899 ve 1907 Lahey Sözleşmeleri ile 1935 Washington Paktı ilkelerinin rehber alındığı belirtilmektedir. Sözleşmeyle, önceki düzenlemelerden farklı olarak, kültürel mal tanımı ilk kez yapılmış (Md.1), barış zamanında koruma tedbirlerinin alınması (Md.3), daha önceki amblem ve bayraklardan farklı bir tasarıma sahip 'Mavi Kalkan' amblemi (Md.6) (Şekil 3), askeri personelin eğitimi ve özel bir askeri birlik oluşturulması (Md.7) gibi konular düzenlenmiştir. Sözleşmenin getirdiği en büyük yenilik "büyük önem taşıyan başlıca gayrimenkul mallar” için getirilen Özel Koruma rejimidir (Md.8). Sözleşme’de her ikisi de zarar verilmemesi gereken kültürel mal ile Özel Koruma altına alınan kültürel mal arasında koruma gerekliliği ve şartları açısından net bir ayırım yapılmamıştır, ancak özel olarak korunacak kültürel malların belirlenmesi prosedürü ve işaretlenmesi farklıdır. ${ }^{85}$

80 UNESCO, Records of the General Conference 1949, http://unesdoc.unesco.org/images/0011/001145/114590E.pdf (Erişim Tarihi 01 Şubat 2018).

81 Vrdoljak, "Cultural Heritage”, s.271.

82 Sözleşme’ye taraf devletler, Tüzük ve Protokol’e ayrıca taraf olmaktadırlar. Yaratacağı olası rejim bütünlügü sıkıntılarının yanı sıra, bu sistem Tüzük ve Protokol ve daha sonra imzalanmış olan İkinci Protokol'e taraf devlet sayısında azalmaya sebep olmuştur.

83 Türkiye konferansa katılan imzacı devletlerden biri olmasına rağmen, Sözleşme ve Protokol ancak on yıl sonra 8 Kasım 1965 tarihinde 12145 sayılı Resmi Gazete'de yayınlanarak yürürlüğe girmiştir.

84 UNESCO, States Parties, http://www.unesco.org/new/en/culture/themes/armed-conflict-and-heritage/conventionand-protocols/states-parties/ (Erişim Tarihi 01 Şubat 2018).

851954 Lahey, Md.8, Md.16; Tüzük, Bölüm II. 
Şekil 3. 1954 Sözleşmesi ve 1999 İkinci Protokol Mavi Kalkan Amblemleri
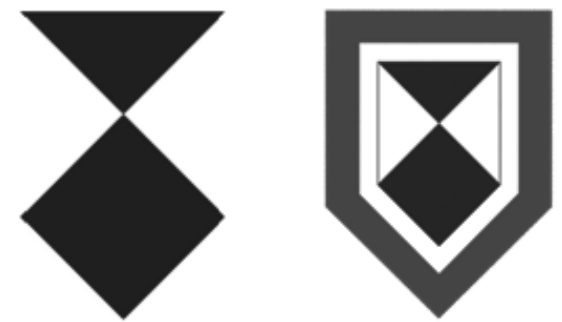

Kaynak: UNESCO, Blue Shield, http://www.unesco.org/new/en/culture/themes/armed-conflict-and-heritage/ convention-and-protocols/blue-shield-emblem/ (Erişim Tarihi 01 Şubat 2018).

1954 Sözleşmesi ilk defa kültürel mal teriminin kapsamını belirlemiştir, buna göre aşağıda belirtilen menkul ve gayrimenkul mallar ve bunların korunduğu, sergilendiği binalar ve sığınaklar ile çok sayıda bu ve benzeri mal ve binayı içine alan merkezler kültürel mal olarak sayılmaktadır (Md.1):

[d]inî veya lâik, mimari, tarihi antlarla sanat antları, arkeolojik değerlerdeki yerler, bütünü itibariyle tarihi veya artistik bir alâka arzeden yapı toplulukları, sanat eserleri, el yazmaları, kitap ve başkaca tarihi, artistik veya arkeolojik değer taşıyan eşya, keza yukarıda bildirilen servetlerden mürekkep bilim koleksiyonlarıla önemli kitap, arşiv, röprodüksiyon koleksiyonları ve emsali gibi milletlerin kültür mameleklerinde büyük önemde yeri olan menkul ve gayrimenkul mallar.

Kültürel malı taşınmaz mallarla sınırlayan Lahey Sözleşmelerinden farklı olarak, 1954 Sözleşmesi taşınabilir malları da kültürel mal olarak kabul etmiş, böylece kültürel mal kapsamı genişlemiştir. Diğer taraftan, Lahey Sözleşmeleri'nden farklı olarak, tanımda "büyük önemde yeri olan” denilerek, kültürel mallara bir sınırlama da getirilmiş olur. ${ }^{86}$ Bu sınırlama sonucunda, 1939 OIM Antlaşması'nda 'çok büyük tarihsel değere sahip kültürel mallar' için düşünülen özel koruma rejimi, 1954 Sözleşmesi’nde 'büyük önem taşıyan kültürel mallar' için 'Özel Koruma' rejimi olarak düzenlenmiş, 1999 tarihli İkinci Protokol'de ise ‘Gelişmiş Koruma’ şeklinde revize edilmiştir.

İsteğe bağlı olarak taraf olunan Birinci Protokol, ${ }^{87}$ çoğunlukla Sözleşme hükümlerinin açıklanması ve uygulanmasına yönelik talimatları düzenlemekle birlikte, önemli bir yeni hüküm de getirmektedir. Buna göre çatışma sırasında kültürel mallar sadece silahlı saldırılardan değil, yağma, kaçakçılık ve yasadışı ticaretten de korunmalıdır. Bunun için bir çatışma sırasında taraf devletler, kültürel malların yasadışı yollarla ülkeden çıkarılmasına engel olmak, tespiti halinde yetkili devlete iadesini sağlamak, kendi ülkelerinde koruma altına alınmış muhasım devletlerin kültürel mallarını korumak ve çatışma sonrasında yetkili tarafa iade etmekle yükümlüdürler. ${ }^{88}$ Böylece ilk kez 1939 OIM Antlaşması'nda düzenlenen ancak yürürlüğe giremeyen ve daha sonra II. Dünya Savaşı sonrasında kurulan mahkemelerde Almanya’ya kaçırılmış olan kültürel malların iadesi şeklinde alınmış kararlar, Birinci Protokol ile yerinden edilmiş kültürel malların ilgili devlete iadesi maddesi ile bir uluslararası hukuk kuralı haline gelmiştir. ${ }^{89}$

86 Schipper ve Frank, A Concise Legal History, s.16.

87 1954 Lahey Silahlı Bir Çatışma Halinde Kültür Mallarının Korunmasına Dair Sözleşmeye Dair Protokol, http://ua.mfa. gov.tr/detay.aspx?2169 (Erişim Tarihi 14 Eylül 2017).

88 Birinci Protokol, Md.I-II.

89 Yerinden alınmış kültürel malın ilgili devlete iadesi konusu, BM Güvenlik Konseyi’nin 1990 Birinci Körfez Savaşı sırasında 661 Sayılı Karar ve 2003 İkinci Körfez Savaşı sırasında 1483 Sayılı Kararı ile Birinci Protokol'de yazılan haliyle, karara bağlanmıştır. Böylelikle, konu sadece Birinci Protokol'e taraf devletler için değil, tüm BM üyesi devletler için bağlayıcı hale gelmiştir. Bkz. Vrdoljak, “Cultural Heritage”, s.277. 


\section{9 Íkinci Protokol}

20. yüzyılın son çeyreğinde yaşanan çatışmalar, özellikle eski Yugoslavya ve Körfez Savaşlarındaki tahrip ve yağma olayları, UNESCO'nun 1954 Sözleşmesi'ni gözden geçirmeye itmiştir. Bu doğrultuda 1999'da, Sözleşme'yi tamamlayacak yeni bir protokol hazırlanır. İkinci Protokol olarak adlandırılan, 29 Mart 1999 tarihinde imzalanarak 9 Mart 2004'te yürürlüğe giren protokolde, daha etkin bir uygulama için gerekli bazı yeni ve ek tedbirler düzenlenmiştir. ${ }^{90}$ Sözleşme'ye taraf devletler İkinci Protokol'e ayrıca taraf olmaktadır. Türkiye'nin taraf olmadığı İkinci Protokol’e 2018 itibari ile sadece 74 ülke taraftır. $^{91}$

İkinci Protokol'ün getirdiği en önemli değişiklik, Sözleşme’de II. Bölüm’de düzenlenen Özel Koruma dışında, Gelişmiş Koruma olarak yeni bir sistem getirmesidir. ${ }^{92}$ Sözleşme'de devletler sadece kendi ülkelerindeki kültürel malların korunmasını teklif edebilirken, İkinci Protokol'e göre diğer taraf devletler de başka bir taraf ülkedeki kültürel malın koruma altına alınmasını teklif edebilmektedir. Diğer bir yenilik, Sözleşme ve İkinci Protokol hükümlerine aykırı hareket eden kişilerin yargılanarak, bu kişilerin cezalandırılması ve suçluların iadesi konusunda taraf devletlerin gerekli ulusal yasal düzenlemeleri yapmaları gereğidir. ${ }^{93}$

İkinci Protokol ile 'Silahlı Çatışma Sırasında Kültürel Malların Korunması Komitesi' ve 'Silahlı Çatışma Sırasında Kültürel Malların Korunması Fonu' kurulmuştur. Komite, İkinci Protokol'ün uygulanmasını denetlemek ve rehber ilkeleri hazırlamak; teklif edilen bir kültürel malın Gelişmiş Koruma altına alınıp alınmayacağına karar vermek; koruma kararını iptal etmek veya askıya almak; Fon'un kullanımını belirlemek gibi görevler üstlenmiştir. ${ }^{94}$ Bütçesi taraf devletlerin gönüllü katkılarından oluşan Fon'un amacı ise taraf devletlere ihtiyaç duydukları mali desteği sağlamaktır. ${ }^{95}$

1954 Sözleşmesi ve 1999 Ek Protokolü silahlı çatışmalar sırasında kültürel malların korunması rejimini tamamlayan, konuya münhasır tek uluslararası antlaşmadır. Ancak, askeri gereklilik muafiyetinin devam etmesi, rejimin fiilen uygulanmasını sağlayacak Monuments Men benzeri bir icra heyetinin ve sözleşmeye aykırı hareketler için gerekli yaptırım mekanizmalarının olmaması gibi önemli eksikleri vardır. Diğer taraftan, bu tarihe kadar savaş hukuku düzenlemeleri içinde genel bir şekilde ele alınmış konunun münhasır bir şekilde düzenlenmiş olması, rejimin eksiklerinin tamamlanması açısından ilerlemedir. Ancak antlaşma teamül hukuku yaratmamış, zaten teamül hukuku haline gelmiş olan 1899 ve 1907 Lahey ve Cenevre Sözleşmeleri’nin ilgili maddelerini konuya özel ve detaylı bir şekilde düzenlemiştir. Bu yüzden Sözleşme'nin özel hükümleri sadece taraf devletler için bağlayıcı iken, kültürel mallara zarar verilmemesi ve askeri gereklilik gibi genel hükümleri teamülü yansıtır ve evrensel bağlayıcıllı̆a sahiptir.

901999 Second Protocol to the Hague Convention of 1954 for the Protection of Cultural Property in the Event of Armed Conflict (İkinci Protokol), 26 Mart 1999, http://unesdoc.unesco.org/images/0013/001306/130696eo.pdf (Erişim Tarihi 18 Eylül 2017).

91 UNESCO, States of Parties.

92 İkinci Protokol, Md.10.

93 İkinci Protokol, Md.15-16-17.

94 İkinci Protokol, Md.24-27.

95 İkinci Protokol, Md.29. 
1954 Sözleşmesi de dâhil olmak üzere araştırmada ele alınan uluslararası hukuk düzenlemeleri aynı zamanda savaş hukuku kuralları içerdiğinden, kültürel malların korunması rejimine aykırı hareket eden kişiler savaş suçu veya insanlığa karşı suç kapsamında yargılanabilmektedir. ${ }^{96} 1998$ yılında kurulan Uluslararası Ceza Mahkemesi'nin (UCM) Statü Md.8.2(b)ix ile uluslararası olan ve olmayan çatışmalarda; "Askeri amaçlı olmaması koşuluyla din, eğitim, sanat, bilim veya yardım amaçlarıyla kullanılan binalara, tarihi eserlere, hastanelere ve hasta ve yaralıların toplandığı yerlere kasten saldırı” savaş suçu olarak kabul edilmiş ve Mahkeme'nin yargı yetkisine dâhil edilmiştir. UCM’ye devredilen Bosna Savaşı sırasında kültürel mallara yönelik suçlarla ilgili mahkemelerin kararları ve 'tarihi bir içtihat' olarak değerlendirilen Timbuktu kararı ${ }^{97}$ ile UCM, kültürel mallara kasıtlı olarak zarar verilmesinin ciddi bir suç olduğunun ve cezasız bırakılmaması gerektiğinin altını çizmektedir. ${ }^{98}$ Kültürel malların korunmasına yönelik uluslararası hukuk düzenlemelerinin gelişmesinin yanı sıra rejime aykırı fiillere verilen cezaların artması, caydırıcılık sağlaması ve dolayısıyla kültürel malların daha iyi korunabilmesi bakımından önemlidir. Ancak UCM ile kültürel mallara yönelik saldırıların cezalandırılmaya başlanması da, silahlı çatışmalar sırasında kültürel malların zarar görmesini engelleyememektedir.

Kültürel mallar silahlı çatışmalar harici dönemde de koruma altına alınmaya çalışılmıştır. Bu durum kültürel malların, günümüzde giderek artan stratejik yorumlarından ve kullanımlarından kaynaklanmaktadır. Kültürel malların toplumsal ve ekonomik değişimler gibi her türlü bozulma ve yok olma tehlikesinin önüne geçilmesi için, 1972'de Dünya Kültürel ve Doğal Mirasının Korunmasına Dair Sözleşme ve bu sözleşmenin kapsamı dışında kalan 'yaşayan miras' ${ }^{\text {'99 }}$ alanlarının korunması için 2003’te Somut Olmayan Kültürel Mirasın Korunması Sözleşmesi imzalanmıştır.

Kültürel malların, tüm uluslararası toplumun ortak mirası olmasının yanı sıra, 2003 UNESCO Somut Olmayan Kültürel Mirasın Korunması Sözleşmesi'nin dibacesinde vurgulandığı gibi, "insanları birbirlerine yakınlaştırıcı ve onlar arasında değiş tokuşu ve anlayışı sağlayıcı, paha biçilmez rolü” vardır ve toplumlar için "sürdürülebilir kalkınmanın güvencesi”dirler. ${ }^{100} 2014$ yılında Avrupa Birliği Konseyi'nin yayımladığı sonuç raporunda kültürel miras "demokratik, etik, estetik ve ekolojik değerler üzerine kurulu bir toplum yaratma açısından stratejik bir kaynak" (vurgu yazara aittir) olarak tanımlanmakta, "kültürel, çevresel, sosyal ve ekonomik açılardan topluma büyük değer kattığı ve bu kaynakların sürdürülebilir yönetiminin 21. yüzyıl açısından stratejik bir seçim

96 Rejimi oluşturan uluslararası hukuk maddelerine aykırı hareket edenler ilk kez II. Dünya Savaşı́ndan sonra kurulan Nürnberg Uluslararası Askerî Ceza Mahkemesinde yargılanmıştır. Nürnberg'ten sonra kültürel mallara yönelik saldırıların yargılandığı ad hoc mahkemeler şunlardır: ICTY; Ruanda için Uluslararası Ceza Mahkemesi Şartı, Md.4; BM SC Res.955 (8 Kasım 1994) ve ek SC Res.1717 (13 Ekim 2006); Sierra Leone Özel Mahkemesi Statüsü BM SC Res 1315 (14 Ağustos 2000); Olağanüstü Kamboçya Mahkemesi Res.57/228B, Doc. A/RES/57/228B (22 Mayıs 2003), NS/RKM/1004/006 (27 Ekim 2004). Vrdoljak, “Cultural Heritage”, s.265-266.

972012 yılında Timbuktu'da Mali kültürüne ait koruma altındaki 10 türbenin yok edilmesi emrini veren Ahmad al-Faqi Al Mahdi, kasıtlı olarak dini ve kültürel mirasa saldırarak savaş suçu işlediği gerekçesi ile 2017 yılında Uluslararası Ceza Mahkemesi tarafından 9 yıl hapse mahkûm edilmiş ve toplamda 2,7 milyon Euroluk zarardan sorumlu tutulmuştur. ICC, Al Mahdi case: ICC Trial Chamber VIII issues reparations order, Case No. ICC-01/12-01/15, 2017 https://www.icccpi.int/Pages/item.aspx?name=pr1329, (Erişim Tarihi 07 Temmuz 2018).

98 UNESCO, International Criminal Court and UNESCO Strengthen Cooperation on the Protection of Cultural Heritage, http://whc.unesco.org/en/news/1742, 2017 (Erişim Tarihi 07 Temmuz 2018).

99 UNESCO Türkiye Millî Komisyonu, “Somut Olmayan Kültürel Miras İhtisas Komitesi”, http://www.unesco.org.tr/ Pages/52/19/Somut-Olmayan-K\%C3\%BClt\%C3\%BCrel-Miras-\%C4\%B0htisas-Komitesi (Erişim Tarihi 04 Ekim 2018).

100 UNESCO, “Somut Olmayan Kültürel Mirasın Korunması Sözleşmesi”, 2003, https://ich.unesco.org/doc/src/00009-TR-PDF.pdf (Erişim Tarihi 04 Ekim 2018). 
olduğu” vurgulanmaktadır. ${ }^{101}$ Görüldüğü üzere, kültürel mirasa başta atfedilen soyut önem, gittikçe somut hale gelmiş ve 21 . yüzyıl kalkınma politikalarının temel parçası olarak değerlendirilmeye başlanmıştır.

Bendix’e göre kültürel miras her dönemde stratejik kullanıma açlk olmuştur ve öyle olmaya devam edecektir. Bendix'in stratejik kullanım kavramı; her türlü kültürel mirasın, ona sahip topluluğun değişen ihtiyaçları karşısında, zamanın değişen ruhuna uygun olarak farklı işlevlere sahip olacağını vurgulamaktadır. ${ }^{102}$ Endüstrileşme çağı sonrası Avrupa Birliği’nin kültürel mirasa yönelmesi de bu açıdan değerlendirilebilir. Diğer taraftan bu durum, belli bir kültürel mirasın sembolize ettiği anlama veya o kültürel malı sahiplenen toplumlara duyulan öfke ve toplumlar arası çatışmalarda, o kültürel malı, bir kültürel miras konumundan çıkarıp düşman hedefi konumuna getiren farklı bir stratejik anlam da yaratmaktadır. Bu durumda kültürel mallar, bir taraftan kuşaklar arası ve kuşaklar içi topluluklar arasındaki aynılık ve sürekliliği, diğer taraftan da farklılık ve hoşgörüsüzlügü vurgulayan bir stratejik anlam taşımaya başlar. Kültürel malların bu tür stratejik yorumları, onu hem daha değerli hem de daha korunmasız hale getirmiştir.

1992-1995 Bosna Savaşı’nda, 2003 Irak Savaşı́nda; kontrolü ele geçirdiği 1996 yılından beri Afganistan'da Taliban ve 2013 yılından beri Suriye'de Irak ve Şam İslam Devleti (DAEŞ) eliyle kültürel mallar artan bir hızla zarar görmeye devam etmektedir. Asimetrik karakterde olan bu çatışmalarda, düşmanın ya da düşman ideolojinin birer sembolü olarak kültürel mallar başlı başına bir nefret unsuru olarak algılanmakta ve özellikle hedef alınmaktadır. ${ }^{103}$ Örneğin Taliban örgütü Buda heykellerini putperestlik sembolü saydıkları için yıkarken, Sırplar Mostar Köprüsü’nü Hırvat ve Boşnak toplumlar arasındaki birliği simgelediği için yıkmışlardır. ${ }^{104}$ Benzeri eylemler, kültürel malların yukarıda vurgulanan stratejik kullanımlara örnek teşkil etmektedir.

\section{Sonuç}

Araştırma, kültürel malların korunması gerekliliği konusunda tarihsel bir ortak kanının var olduğunu göstermekte, neden korunması gerektiği yönündeki düşüncelerin ise zamanın değişen ruhuna uygun biçimde şekillendiğini ortaya koymaktadır. Tarihsel gelişim, konunun önce savaş hukuku sözleşmelerinde genel bir şekilde ele alındığını, zamanla daha detaylı hükümlerle düzenlendiğini, rejimin geliştirilmesi yönündeki çabaların savaş sonrası dönemlerde arttığını, ancak bu çabaların sonraki çatışma dönemlerinde yetersiz kaldığını göstermektedir.

Bu durum 21. yüzyılda kültürel mallara en çok zarar veren çatışmaların asimetrik ve etnik/ dini kökenli saldırılar olması gerçeği ile de örtüşmektedir. Kültürel mallar bu çatışmaların ruhuna uygun şekilde, askeri ve siyasi birer stratejik hedef haline gelmiştir. 20. yüzyılın tüm kodifikasyon

101 Avrupa Birliği Konseyi, "Conclusions on cultural heritage as a strategic resource for a sustainable Europe”, 20 May1s 2014, http://resources.riches-project.eu/wp-content/uploads/2015/11/conclusion-cultural-heritage.pdf (Erişim Tarihi 04 Ekim 2018).

102 Regina Bendix, “Tourism and Cultural Displays: Inventing Traditions for whom?”, Journal of American Folklore, Cilt 102, No.404, s.143.

103 Joris D. Kila, "Inactive, Reactive, or Pro-active?: Cultural Property Crimes in the Context of Contemporary Armed Conflicts", Journal of Eastern Mediterranean Archaeology and Heritage Studies, Cilt 4, No.1, 2013, s.319-320.

104 Kila, Inactive, s.325; András J. Riedlmayer, "Crimes of War, Crimes of Peace: Destruction of Libraries during and after the Balkan Wars of the 1990s”, Library Trends, Cilt 56, No.1, 2007, s.119-120. 
çabaları, uluslararası hukuk kurallarının bağlayıcılığına güvenilerek hazırlanmıştır. Ancak bu kuralları tanımayan ulus-altı aktörler karşısında yetersiz kalmaya devam etmektedir.

Bütün çabalara rağmen kültürel malların zarar görmeye devam etmesi, sadece rejimin eksik yönlerinin değil, tümden varlık sebebinin de sorgulanmaya başlanmasına neden olmuştur. Posner'e göre, rejimi geliştirmek için önerilen çareler yersiz ve yetersizdir, bunlar yerine kültürel mallar sivil mallar ile bir tutulmalı, serbest piyasa kurallarına göre düzenlenmeli ve zaten teamül kuralı halindeki uluslararası insancıl hukuk ile koruma altına alınmalıdır. ${ }^{105}$ Posner'in rejimin etkisizliğine çare olarak sunduğu görüşlerinde, kültürel mallar sahiplik açısından ele alınmakta ve serbest piyasa kuralları tarafından korunabileceği iddia edilmektedir. Rejimin etkinlik sorununu en radikal şekilde çözmekle birlikte, serbest piyasanın neden olabileceği olumsuz etkileri kestirebilmek güçtür. Koruma altında iken dahi kültürel mallar büyük bir karaborsaya sahiptir ve farklı gruplar tarafından farklı stratejik amaçlarla kullanılabilmektedir. Hem savaş hem de barış zamanlarında serbest piyasa koşullarının dinamikleri ile alınıp satılmasına izin verilmesi, taşınabilir kültürel malların fakir ülkelerden zengin ülkelere kaymasına yol açabilecektir. Taşınmaz kültürel malların durumu ise belirsizliğini korumaya devam edecektir.

Rejimin tarihsel gelişimi genel olarak değerlendirildiğinde, kültürel malların taşıdıkları önem nedeniyle her dönem stratejik kullanıma açık oldukları, bu önemlerini gelecekte de koruyacakları, şimdiden öngörülemeyecek olan yeni stratejik kullanımlar karşısında bugünün kodifikasyon çabalarının gelecekte yetersiz kalmaya mahkum olduğu söylenebilir. 